\title{
Communicating Renewable Energy in the National Action Plans of the Member States of the European Union
}

\author{
András Vincze ${ }^{1}$, Nóra Hegedúsné Baranyai ${ }^{2, *}$, Henrik Zsiborács ${ }^{2}$, Szilvia Csányi ${ }^{2}$, \\ István Háber ${ }^{3}$ and Gábor Pintér ${ }^{2}$ \\ 1 Department of Foreign Languages, University of Pannonia, Georgikon Faculty, 8360 Keszthely, Hungary; \\ vinander@t-online.hu \\ 2 Department of Economic Methodology, Georgikon Faculty, University of Pannonia, 8360 Keszthely, Hungary; \\ ifj.zsiboracs.henrik@gmail.com (H.Z.); szilvia.csanyi15@gmail.com (S.C.); pg@georgikon.hu (G.P.) \\ 3 Energia Design Building Technology Research Group, Szentágothai Research Centre, University of Pécs, \\ Faculty of IT and Engineering, 7624 Pécs, Hungary; ihaber@mik.pte.hu \\ * Correspondence: baranyai@georgikon.hu
}

Received: 16 December 2019; Accepted: 24 January 2020; Published: 29 January 2020

\begin{abstract}
For implementing renewable energy policies it is necessary to convince the population of the appropriateness and usefulness of the ideas. The information provision needed for that requires the communication to be accessible and understandable to the target audience. This research examined the national renewable energy action plans of the member states of the European Union. The online accessibility of these documents and their readability were examined using a simple accessibility test and the Flesch and Flesch-Kincaid readability tests. The paper also addresses the relationship between the culturally-determined power distance indices and the economic and developmental characteristics of the countries and the readability values of their samples. The results showed that the examined documents could be easily accessed, but the action plans of all the member states were difficult to read. The emerging pattern suggested that the text samples of the countries with higher power distances were harder to interpret. Nevertheless, no significant relationship was detected by the correlation analyses between the power distance indices and the Flesch and Flesch-Kincaid readability scores, while strong relationships were detected between the Human Development Index (HDI) data and the results of both readability tests in the group of countries with the highest power distance values.
\end{abstract}

Keywords: energy policy; renewable energy; communication; readability; culture; power distance

\section{Introduction and Literature Review}

Besides the most commonly used energy sources, the world's nations of today try to make use of renewable sources of energy to replace fossil fuels. Renewables differ from non-renewable energy by the fact that they are from sources whose supplies can be regarded as continuous from a human perspective, i.e., they are capable of regeneration within a foreseeable period of time.

The issue of the so-called energy transition has, of course, raised the attention of many, and as we can experience it in our everyday lives and see and hear it in the media, there is an increasingly stronger public outcry for switching to more sustainable energy systems based on renewable energy sources. The main reason for this is the public perception that our current energy consumption and production, based mainly on fossil fuels, is to blame for such harmful environmental processes and changes as the ever-growing carbon dioxide emissions and the resulting climate change. 
Considering the enormous social, environmental, and economic importance of the issue, providing stakeholders-and the public in general-with relevant information about the related policies of the governments and supranational organisations has become crucial. However, the fact that such communication takes place is not satisfactory by itself. The information given must be widely accessible, clear, and comprehensible to the target audiences. Therefore, an investigation into how such communication is carried out seems to be conducive to establishing if citizens' rights to be informed are fulfilled and if the clarity and comprehensibility of policy-related documents differ from country to country and/or are influenced by cultural differences or other major economic or developmental characteristics of the nations.

\subsection{Renewable Energies and Renewable Energy Policies in the World}

By now it has become evident that besides energy efficiency it is renewable energy sources (RES) that play the key role in global energy transformation [1]. Their use has demonstrated a considerable increase in recent years (as illustrated by Table 1), partly due to new inventions, technological development, growing competition, and the resulting drastic drop in costs. Consequently, it is of little surprise that in the field of investments in 2017 more money was invested in renewable energy-based electricity capacities than on those based on fossil fuels. In the same year $70 \%$ of the increase in the net electric energy capacity was based on RES, approximately 178 gigawatt [2].

Due to the extraordinary importance of energy it is natural that states have their own energy policies, which, among others, determine principles, goals, and the ways and means of reaching them. Such sophisticated energy policies are all the more important because they are required by the increasingly large and complex systems in general [3]. Moreover, it is also becoming self-evident-because of the trends mentioned above- that specific renewable energy policies are also created.

Table 1. The annual growth of renewable energy consumption by regions of the world and their consumption (based on the gross energy production from renewable sources, including wind, geothermal, solar, biomass, and waste energy, but excluding electric energy transported across borders) as a percentage of global renewable energy consumption in 2018.

\begin{tabular}{cccc}
\hline Region & Annual Growth 2018 & Annual Growth 2007-2017 & Share 2018 \\
\hline North America & $9.6 \%$ & $13.9 \%$ & $21.2 \%$ \\
\hline South and Central America & $12.2 \%$ & $16.4 \%$ & $6.3 \%$ \\
\hline Europe & $6.1 \%$ & $13.1 \%$ & $30.7 \%$ \\
\hline Commonwealth of Independent States & $24.0 \%$ & $14.9 \%$ & $0.1 \%$ \\
\hline Middle East & $34.2 \%$ & $42.1 \%$ & $0.3 \%$ \\
\hline Africa & $18.5 \%$ & $20.4 \%$ & $1.3 \%$ \\
\hline Asia, Australia, and Oceania & $25.0 \%$ & $23.2 \%$ & $40.2 \%$ \\
\hline World total & $14.5 \%$ & $16.4 \%$ & $100.0 \%$ \\
\hline European Union & $4.8 \%$ & $12.8 \%$ & $28.4 \%$ \\
\hline Hungary & $9.9 \%$ & $66.9 \%$ & $0.1 \%$ \\
\hline
\end{tabular}

As a means of influencing the market and the legal environments, the various energy policies have a fundamental role [5]. Although the effectiveness of renewable energy policies is often questionable and they may involve major fiscal and economic costs, and may thusly be controversial [6], more and more countries are deciding to support RES. At the end of 201787 countries had valid goals concerning the share of energy generated from renewable sources in their final energy consumption. Regarding sector-specific goals, 146 nations had valid targets at the same time [7].

These policies, however, cannot only be meant solely for the promotion of the use of RES, but they also have to contribute to the achievement of other social goals [8], and thus their creation 
may be motivated by several reasons and aims. Some of these are related to the urging pressure of environmental problems. Efforts to mitigate climate change and its impacts, for example, are even prescribed by several international conventions. Among these, the Paris Agreement under the United Nations Framework Convention on Climate Change (UNFCCC) of 2015 is of paramount importance, and as of November 2019 it has been signed by 195 UNFCCC members [9].

The renewable energy policies made by various nations and organisations focus on three main sectors, which, together with their subsectors, cover most energy consumption. The most emphasis is laid on electric energy production worldwide. This may be partly because this is the most expensive, transportable, and versatile sort of energy, and there is also a proven relationship between its consumption and the gross domestic product (GDP) [10], as well as economic growth [11]. Another important sector, still receiving much less attention, is that of cooling and heating, within which heating accounts for the largest final energy consumption of all sectors, and in 2015 it was responsible for more than $50 \%$ of the total energy use. The third great area and the second most important regarding final energy consumption is transport, where $29 \%$ of the total energy consumption occurred in 2015. This sector is still highly dependent on fossil fuels, as $96 \%$ of the energy used in transport in the same year came from oil products $[2,12]$.

Miguel Arias Cañete, former European Commissioner for Energy and Climate Action, said: "Policymaking is not about what can be done in theory, but much inspired by practicalities and political feasibility" [13]. In order to implement the objectives of the renewable energy policies, decision-makers use numerous tools. They include, for example, different national and/or international targets and contributions undertaken in connection with RES. The systems of means also depend on various regulations to a great extent, including: feed-in tariffs, the payment of direct supports, the quota obligations of electricity utility companies, net metering and billing, obligations related to transport and heating, renewable energy credits, and systems of tendering. States often use the methods of tax-like incentives and state financing, for example, investment or production tax credits, value-added tax (VAT), energy tax, $\mathrm{CO}_{2}$ tax and other tax reductions, energy production payments, state investments, loans, capital support, and other schemes. Of the above-mentioned ways, according to Kalkuhl and his colleagues [14] and Parry [15] the direct methods are the most effective for reducing $\mathrm{CO}_{2}$ emissions.

\subsection{The Renewable Energy Policy of the European Union}

The European Union's policy on RES is to a great extent based on the Union's standpoint and role concerning environmental and climate protection. The necessity of the reduction of greenhouse gas emissions naturally led to a quest for alternatives, including renewable ones, capable of replacing fossil fuels in the EU, too. The Kyoto Protocol, signed on 11 December 1997, provided the international foundation on which the Union's first specific policies for limiting the emissions of greenhouse gases were created [16].

In the whole world it is the European Union where the most climate protection policies and measures have been made and introduced $[17,18]$. As a result of this, an enormous amount of practical experience has been accumulated in the EU in the past decades. All that knowledge, in turn, affects every aspect of policy-making, resulting in remarkable outcomes in technology development, the mitigation of environmental pollution, and the separation of economic growth and increasing greenhouse gas emissions.

Between 1990 and 2013 the GDP of the 28 member states increased by $45 \%$, while the emission of greenhouse gases decreased by $19 \%$ [13]. This means that the European Union managed to prove that it is possible to reduce greenhouse gas emissions during continuous economic development. This is a great achievement, even if the few decades since the beginning of the processes aiming for energy transition and decarbonisation of the EU, starting in the 1990s, have been too short to come to final conclusions about the success of the implemented policies.

According to the renewable energy directive that defines the current EU renewable energy policy [19], every member state has to create a national renewable energy action plan, in which they 
themselves may determine the means they wish to use to achieve their goals as well as the composition of their energy mixes [20]. They are also allowed to decide on the percentage of renewable energy in each sector except for transport, where in the case of every member state the ratio of the use of bio-fuels has to reach $10 \%$.

In order to reach their national targets the countries may use, among others, various support systems and so-called flexibility measures, which are initiatives for cooperation with other member states or third countries [21]. Support systems are the various tools of the promotion of renewable energies, by which the price of such energy can be raised, its costs can be reduced, or its amount sold can be increased by introducing obligations or any other means. Such solutions may include support for investments, tax exemption and tax advantages, tax refunds, support systems related to renewable energy obligations, and systems of price subsidies, including feed-in tariffs and the payment of grants.

Within the framework of the above-mentioned flexibility measures the directive makes it possible for the individual states to achieve their defined national targets in collaboration with other countries. As the member states have widely varying potentials for the generation of renewable energy, this possibility is of enormous importance because it allows renewable energy to be produced at the location where it can be done the most cost-effectively.

Due to the dynamics of renewable energies and the sectors associated with them, it soon became necessary to rethink the provisions of the renewable energy directive of 2009 [22]. As a part of the energy union programme of the European Commission, the package of proposals titled "Clean Energy for All Europeans" [23], often simply referred to as "Winter Package", was officially published on 30 November 2016. The package can be regarded rather as the result of organic evolution than revolution, and that is why it has been criticised by many as not ambitious enough. Nevertheless, it has become an important part of EU legislation related to energy, and it is a significant step towards the realization of a more and more comprehensive energy union.

Based on the Winter Package, the new renewable energy directive creates a common framework for the promotion of the use of renewable energy in the various sectors. Basically, it provides a legal basis for the realisation of the main goals under the proposals [24]. First of all, the new directive sets down the mandatory comprehensive target for the whole European Union that the share of energy from RES within the energy mix has to be at least $32 \%$ by 2030. (This figure is even higher than the original $27 \%$ of the Winter Package.) This is the first time that self-consumption has been regulated, meaning that consumers or communities of consumers wishing to produce energy are taken into account, and a comprehensive regulatory system for the whole Union has been created for the use of renewable energy besides the generation and use of electric energy and transport.

Regarding the development of the cause of renewable energy in the EU, which is illustrated by Figure 1, it can be concluded that the renewable energy policy of the European Union has made great progress from the beginning to the Winter Package, which will determine the future of the use of RES in the Union in the next few decades. 


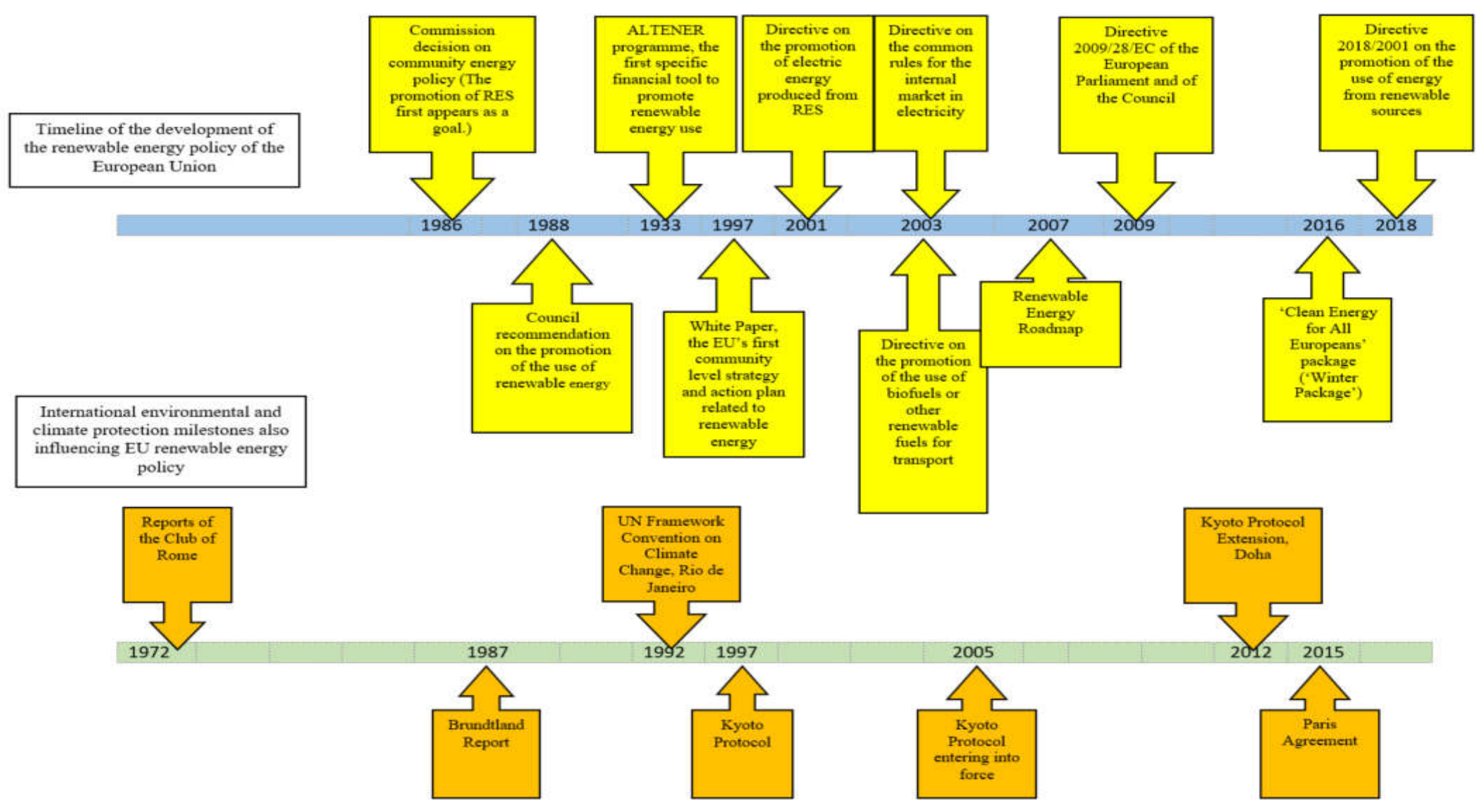

Figure 1. Timeline of the EU renewable energy policy in an international context. Source: the authors' own work based on a report by BP [4]. 


\subsection{Policies and Communication}

Policies, including renewable energy policies, are meant to be implemented in practice. Although administrative and legislative measures are important steps in their realisation at the level of each country, the enactment of law does not automatically lead to the successful implementation of the policy. If the law, the regulations, and the system of support are not received with understanding and acceptance by the affected parties, it may cause partial or complete failure of the policy. Research by Rogers, Simmons, Convery, and Weatherall $[25,26]$ also proved that besides financial support the moral and intellectual backing of the local self-governments, economic actors, and the population is extremely important for the success of local renewable energy projects.

Of course, communication, persuasion, and marketing and/or social marketing play a key role at every level of the process. From the beginning, the birth of an idea, to the realisation of the desired economic or social change, a wide range of people need to be convinced: from policy makers, legislators, service providers, financing institutions, influencers, non-governmental organizations (NGOs), local self-governments, and professional organisations to companies and individuals and groups of individuals, who (in an ideal case) will be the beneficiaries of the changes [27]. It is obvious that from the perspective of reaching a goal, communication and its quality, and whether the message is received by the targeted groups or individuals are fundamental.

\subsection{Readability and Measuring Readability}

The question of readability is often raised in connection with the comprehensibility and clarity of official communication and legislation. Readability has extensive literature in the United States and recommendations, tests, and assessment methods are widely used for practical purposes. In spite of the fact that concerning English there is much research done in the field of the assessment and assessment methods of readability, this is not the case regarding other languages [28].

Before embarking upon an introduction of the methodologies of measuring readability, the notion of readability itself needs to be clarified. According to DuBay's [29] simple but useful definition, readability is the characteristic of written texts that makes one text easier to read than others. As part of his definition he also clarifies that readability is not to be confused with legibility. According to a more comprehensive definition by Dale and Chall [30], readability refers to the entirety of the elements (and their interplay) within a given printed text that determine with what success a particular group of readers can read it. By "success", the authors mean the level of comprehension, the optimal speed of reading, and raising and maintaining interest.

As regards the research and practical use of readability thusly defined, it is worth going back to DuBay [29], according to whom it was already in the second half of the 20th century that readability formulas became widespread in the market and they started being used in many fields, including journalism, research, the industry, law, insurance, healthcare, and even the US army in its technical teaching materials. Norman Otto Stockmeyer [31], a professor emeritus of the Thomas M. Cooley Law School and former president of Scribes-The American Society of Legal Writers, opines that it is lawyers in particular who have to be especially careful to make sure that their readers can understand their writings.

Loughran and McDonald's [32] research demonstrated that readability and the assessment of readability can have practical effects on business success, and they are closely related to the issue of management too. Their project, in which the annual financial reports of companies were analysed, proved that readability had a great impact on investors, i.e., better readability induced greater activity among them. On the other hand, it was also established that companies with more democratic management styles laid more emphasis on using simpler language. Firms with shareholder-friendly cultures produced more easily readable reports. That observation has important implications for this research too, since according to our hypothesis such differences between (organisational) cultures must be perceivable also at the level of policy-making and legislation. 
The measurement and formulas of readability can look back on a long history [29]. In connection with the reading capabilities of the population of the USA, the first formulas were already developed in the first half of the 20th century to predict the difficulty levels of written texts. Later, many started to study the issue of readability, and by the 1980s about 200 different formulas had been created, with more than a thousand articles on the topic. At that time there were also formulas for the assessment of readability in Spanish, French, German, Swedish, Russian, Hebrew, Hindi, Chinese, Vietnamese, and Korean [33].

Although science has given the world many methods and formulas to measure the readability of texts, one of the most widely used applications is probably the readability assessment feature of Microsoft Word. Upon completion of a full spellcheck on a Word document the appearing window delivers readability statistics on the text. Unfortunately, the content of the service differs from language to language. While in the case of the Hungarian language all what one gets is basically the number characters, words, and sentences, for English texts the averages, the readability values, and the percentage of sentences in passive voice are also given.

The readability figures thusly obtained for English texts in Microsoft Word are the scores of the so-called Flesch and Flesch-Kincaid readability tests. The method developed by Rudolf Flesch in 1949 [31] works with the average number of syllables per word and the average number of words per sentence in the text, and then draws conclusions regarding the reading difficulty. The higher the figure is on a scale from 0 to 100 , the easier the given text is to interpret.

The Flesch-Kincaid method was based on the research of J. Peter Kincaid in the 1970s. He changed the formula by Flesch, so that a grade level (a level of education) necessary for the reading of the examined text would be given. A higher score indicates the necessity of higher levels of schooling. Stockmeyer also remarks that although neither of the two methods is $100 \%$ reliable, they are not worse than any other general psychological tests in that respect, and they work well because they operate with simple word and sentence lengths, which are the primary factors causing reading difficulty. Nevertheless, one must be wary of striving only for the shortness of words and sentences, since that may become counterproductive, because other factors need to be taken into account too, such as the structure and layout of the texts, as well as the approach and the tone.

\section{Materials and Methods}

\subsection{The Documents and Samples Examined}

The subject of this research is the accessibility and quality of the communication related to the use of renewable energy in the national action plans of the EU member states and the EU legislation requiring them. These documents also comprise the corpus of the investigation. According to the definition of the Hungarian concise dictionary of linguistic terms [34], a corpus is a collection of texts that are selected and studied by scholars according to previously determined criteria.

The samples examined herein were chosen by the so-called varying probability sampling method, as defined by Krippendorf [35]. This means that the units to be studied were selected according to criteria we had established previously. These were the relevance from the perspective of the subject of our research, comparability, and the linguistic aspects.

The most important criterion of relevance in our case was that the examined texts were all determining the currently effective renewable energy policy of the EU and/or the respective policies of the individual member states. By the linguistic criterion, we mean that for the investigation it was indispensable to use the English translations of the originals. This was also crucial in order to comply with the requirement of comparability, since a readability test can only deliver comparable results if they are not distorted by differences between the languages. Regarding the criterion of comparability, we considered it to be fortunate that all the documents studied showed similar genre-specific features-they were all written for publication in an official and formal style. The homogeneity of the samples was further enhanced by the fact that the European Commission had issued a detailed 
guide for the preparation of the national action plans in Commission Decision 2009/548/EC [36]. It was also because of the aspect of comparability that the text excerpts actually analysed were all taken from corresponding chapters of the renewable energy action plans.

As stated above, the corpus of the examinations was based on texts either by the European Union or the member states. The first EU document was none other than the one calling for the national action plans, Directive 2009/28/EC of the European Parliament and of the Council [19], the direct predecessor of which was the Commission's Renewable Energy Roadmap of 2007. As for the documents by the member states, the investigation involved the national action plans in power at present. These accounted for the lion's share of the corpus. Concerning the document type, they were detailed reports submitted by the specific countries under the stipulations of the Renewable Energy Directive [19].

The legal act that determines the current EU renewable energy policy directly and those of the member states indirectly — by obliging them to create their national action plans—is Directive 2009/28/Ec of the European Parliament and of the Council on the promotion of the use of energy from renewable sources and amending and subsequently repealing Directives 2001/77/EC and 2003/30/EC [19]. As for its genre, it belongs to the written, formal type of legal texts. Laws as documents [37] are characterised by being general, looking forward, and always having some degree of obligatory force.

Together with regulations, decisions, opinions, and recommendations, EU directives belong to the category of secondary EU law. EU directives are so-called unilateral acts that are binding for the affected member states only regarding their goals, while the mode, form, and tools of reaching them is left to the discretion of individual countries, together with fitting them into their own national legal systems. Consequently, they are not as detailed as the regulations but rather set down general principles concerning the expected objectives. In the case of the directives, the member states themselves have to create the national legal acts that correspond to the respective directive within the framework of their national legislations and before the set deadline. This may take place by supplementing and/or amending existing acts or by completely new legislation. The obligations and rights deriving from a directive become binding and applicable for the citizens of the member states only after the given member states have transposed them. Since the countries have the possibility of certain consideration related to the transposition of the directives, there is some opportunity to also take national differences into account [38].

Besides prescribing the national renewable energy action plans, the renewable energy directive also made provisions for the creation of a template according to which the member states would have to prepare them (Commission Decision 2009/548/EC of 30 June 2009 [36]). The member states had to present their national action plans concerning the use of renewable energy to the Commission by 30 June 2010. The action plans, together with any recommendations, were then sent by the Commission to the European Parliament.

To sum up, the national renewable energy action plans, which were prepared by all the EU member states and Iceland and Norway, are actually detailed roadmaps regarding how the given countries wish to achieve their legally binding targets for 2020. The current target for the European Union as a whole is that at least $20 \%$ of the energy consumed must come from renewable energy sources. Within this common goal the targets set by the individual countries show great variation.

As is evident from the above, the action plans were primarily made for the Commission and the European Parliament. Still, it cannot be said that they were only meant for the politicians and officials of these two organs of the EU. The documents are widely available, and thanks to the Internet anyone can easily find them. It can be assumed that they are read by all those who want to keep themselves informed either for political, professional, or personal reasons concerning the member states' plans related to renewable energies, future possibilities, or just want to find out about the given countries' commitments to the use of RES. Nevertheless, it must be noted that, since the national action plans only contain information on principles, targets, and general information, the actual national support systems, schemes, and other relevant legislation cannot be found in them, so they are not suitable for direct personal or business decision-making. 


\subsection{The Accessibility Test}

In the course of the research we first sought answers to the question of how easily available the examined documents were to the wider audience, the general public. By doing so, what we hoped to shed light on was the extent to which EU citizens' rights to information under the Charter of Fundamental Rights was observed regarding the renewable energy policies and the national action plans.

Of the news and information sources accessible to the average citizen this study only dealt with the Internet, since-similarly to other parts of the world-in the European Union most people consider the World Wide Web to be the main and most frequently used source of information. According to data from Eurostat, concerning all of the 28 member states $89 \%$ of all households have access to the Internet, which is used on a daily basis by $76 \%$ of the EU citizens aged 16-74 [39]. Based on this, it can be duly assumed that most people also use the Internet to get to know the renewable energy policies of the European Union as well as their respective countries.

As an element of the investigation, we examined by a simple method how many clicks it took an average user to find a particular document by using the search engine of Google, whose market share regarding the European search engines was more than 90\% between August 2018 and August 2019 [40]. First, the search terms (e.g., EU renewable energy directive, the name of the given country and renewable energy action plan (in English and in the official language of the specific country)) were typed in, and then, in step two, clicking on search (click number 1) the user came to a page containing the search results, where, in step three, clicking the link that seemed to be the most relevant (click number 2) took one to further sites, until the required document or a link to a downloadable copy of that was found. After that, in the final step, it was also established whether the documents were accessible in a downloadable format or only to be read online.

Another exciting question was that of the languages, since in our increasingly globalised world it is not only in the traditionally bi- or multilingual countries (e.g., Belgium) where it may become necessary to provide information in more than one language, but for a variety of reasons citizens of other countries might also be interested in a particular country's renewable energy policy. Additionally, in many EU member states there may be numerous residents who cannot speak the official languages of the given countries, but they also have the right to be informed.

\subsection{The Readability Tests}

Investigating the communication of renewable energy in the member states of the European Union and the accessibility of information, it seemed to be natural-besides the issue of the online availability of the documents themselves-to explore how accessible the information in the national action plans is to the lay reader in terms of readability and comprehensibility.

For this purpose the most obvious and-regarding the counting of the linguistic elements-also the most reliable method [41] was the statistics feature of the Microsoft Word word processing software. Microsoft Word uses two methods for testing readability. The Flesch Reading Ease Score (FRES) test was developed by Rudolf Flesch [42]. The score is calculated according to the following formula:

$$
\text { Flesch Reading Ease Score }=206.835-(1.015 \times \text { ASL })-(84.6 \times \text { ASW }) .
$$

Here, ASL means the average length of sentences, i.e., the total number of words divided by the total number of sentences, while ASW stands for the average number of syllables per word, i.e., the total number of syllables divided by the total number of words. The score thusly obtained is a number from 1 to 100, whose value is in an inverse relationship with the difficulty of reading the given text. In the case of a score of 30 or below the text is very difficult to read, while texts with scores of 70 or higher are considered to be easy to interpret.

The Flesch-Kincaid readability test and the formula associated with it were created as a simplified version of the Flesch readability index, and it is also based on the average sentence length and the average number of syllables in the words of the analysed texts [43]: 


$$
\text { Flesch-Kincaid Grade Level }=(0.4 \times \text { ASL })+(12 \times \text { ASW })-15.59 \text {. }
$$

Here, grade level refers to a US school grade level minimally needed to be able to read and comprehend the given text [44]. As the number can be really high, it may also be interpreted as the number of years spent in education necessary to read a particular piece of writing. However, while it is rather difficult to determine how much knowledge a person may be able to attain during $8,13.5$, or even 25 years of education and what texts one can understand with that knowledge, it can be said that the Flesch-Kincaid grade level can be a useful tool for comparative examinations.

The readability analysis herein consisted of six phases. First of all, due to the subject of the research, i.e., the communication of the use of renewable energy in the EU countries' renewable energy action plans, it was obvious that the source to be studied was the national action plans themselves. The main criteria of the selection of the actual samples taken from these were the relevance from the perspective of the subject, comparability, and the linguistic aspects, as also mentioned earlier. Considering these, a chapter of the English translation of the action plans that provides a comprehensive presentation of the countries' plans related to their renewable energy policies, and also contains relatively long passages of continuous text, had to be chosen. The latter aspect was of utmost importance, since the performance of a readability test requires coherent texts long enough for analysis. According to the provisions of the Commission Decision, which had clearly prescribed the structure to be followed for the action plans, it was the first chapter, titled "Summary of National Renewable Energy Policy" that satisfied these requirements. The total sample included the summarising chapters of all 28 countries' action plans.

Secondly, the selected chapters needed to be converted to a suitable format, followed by the third step: running the English-language spell checker of Microsoft Word on each text. In step four the data were simply copied from the statistics windows displayed at the end of the process. This was followed by the tabulation of the figures in the fifth step and the evaluation of the results, which was the sixth, final step.

The following figure (Figure 2) summarises the process of the readability analyses.

\begin{tabular}{|c|c|c|c|c|c|}
\hline $\begin{array}{c}\text { Source } \\
\text { selection }\end{array}$ & $\begin{array}{c}\text { Sample } \\
\text { selection }\end{array}$ & $\begin{array}{l}\text { Preparation } \\
\text { of files }\end{array}$ & $\begin{array}{c}\text { Readability } \\
\text { tests }\end{array}$ & $\begin{array}{c}\text { Processing } \\
\text { quantitative } \\
\text { data }\end{array}$ & Evaluation \\
\hline $\begin{array}{l}\text { - national } \\
\text { action plans }\end{array}$ & $\begin{array}{l}\text { - relevance } \\
\text { from the } \\
\text { perspective of } \\
\text { the topic } \\
\text { - } \\
\text { comparability } \\
\text { - linguistic } \\
\text { aspects }\end{array}$ & $\begin{array}{l}\text { - converting } \\
\text { files to } \\
\text { Microsoft } \\
\text { Word format }\end{array}$ & $\begin{array}{l}\text { - running } \\
\text { the spelling } \\
\text { checker } \\
\text { application } \\
\text { of } \\
\text { Microsoft } \\
\text { Word }\end{array}$ & $\begin{array}{c}\text { - retrieving } \\
\text { readability } \\
\text { statistical } \\
\text { data } \\
\text { - tabulation of } \\
\text { data }\end{array}$ & $\begin{array}{c}\text { - comparison } \\
- \\
\text { interpretation } \\
\text { - examination } \\
\text { of } \\
\text { relationships }\end{array}$ \\
\hline
\end{tabular}

Figure 2. The flowchart of the readability analysis. Source: the authors' own work.

\subsection{Statistical Methods}

According to Hunyadi and Vita [45] the relationships were analysed between the attributes. In the selection of the correlational methods the measurement scales of the attributes were taken as a base. 
In the correlation analyses the relationship between two attributes was examined. The dependent and the independent variables were differentiated. During the application of the regression functions the greatest care was taken to use the function that provided the best fit. The correctness of the regression models was tested by variance analysis, F-test ( $p<0.05$ indicated the existence of a significant relationship). The higher the $\mathrm{R}^{2}$ value, the more closely the regression line fits the set of points.

\section{Results}

\subsection{Results of the Accessibility Test}

The renewable energy directive (2009/28/EC) [19] and the member states' action plans for the utilisation of energy from renewable sources are all easy to find for all on the Internet. During the testing it was established that by a maximum of four mouse clicks all the documents were accessible, and they were also all available for downloading; thus they could be saved for future study even without Internet connection.

With regard to the languages it was observed that the national action plans were available, besides English, in the/some of the official languages of the particular member countries, except for Greece and Malta. Moreover, the national language versions could be accessed by fewer mouse clicks than the English versions in the case of 19 out of the 28 states. Concerning the countries with more than one official language, interesting differences were discovered. In the case of Belgium the plans can be read in two of the official languages, French and Dutch, but not in the third official language, German, spoken only by less than 1\% of the population [46]. In contrast, apart from the official English language, the Irish action plan is also available in the other official language of the country, Irish, which is only used by $4.2 \%$ of the population on a daily basis [47]. The action plan of Luxembourg is only available in German, besides the international English version, in spite of the fact that the country has three official languages: Letzebuergesch, French, and German. As for the Finnish plan, it can be read in Finnish and English but it is not available in Swedish, which is the second official language of the country. Concerning the availability of the national renewable energy action plans in the languages of other national minorities living in the member countries no data have been found on the Internet.

The summary of the renewable energy directive (2009/28/EC) can be read in all 24 official languages of the European Union. Conversely, the full text is only available in 23; it is not in Irish. This may be due to the statistical data on the use of the Irish language referred to above.

Besides all the above, however, it is also important to mention that if someone would like to use the website of the European Commission instead of the Google search engine to access, for example, the national action plan of Hungary in the national language, the search will be less convenient. Opening the starting page of the official website [48], one has the possibility of choosing their national language. Then, after selecting Topics one can choose Energy. At this point, however, an English page opens, where there are no more language options. If the visitor of the website has not been discouraged and can read English, they can proceed by clicking Renewable Energy to get to another English-only page, where they can select the link that opens the next English-only page, which lists all the national action plans. Here, one can access a further window, where they can download the required national action plan.

In conclusion, as a result of the accessibility tests (shown in Table 2), it can be said that the examined documents can be easily accessed and downloaded on the Internet, in most cases also in the official languages of the respective countries. Nevertheless, the issue of the languages of the national minorities, some of which are spoken by millions, raises an important question, the same way as the fact that certain important pages of the European Commission can only be read in English. 
Table 2. Results of the accessibility test.

\begin{tabular}{|c|c|c|c|}
\hline Country & Clicks English & Clicks Official/Further Language & $\begin{array}{c}\text { Search Terms in National Languages } \\
\text { /Name of Country + Renewable Energy Action Plan/ }\end{array}$ \\
\hline 1. Austria & 3 & 2 & Österreich erneuerbare Energien Aktionsplan \\
\hline \multirow{2}{*}{ 2. Belgium } & \multirow{2}{*}{3} & 2 & Belgique plan d'action sur les énergies renouvelables \\
\hline & & 2 & België actieplan hernieuwbare energie \\
\hline 3. Bulgaria & 4 & 3 & България план за действие за възобновяема енергия \\
\hline 4. Cyprus & 4 & 3 & 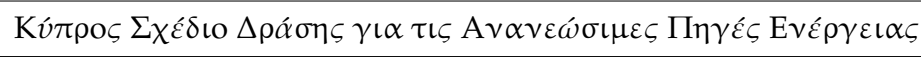 \\
\hline 5. Czech Republic & 2 & 2 & Česká Republika akční plán pro energii z obnovitelných zdrojů \\
\hline 6. Denmark & 3 & 2 & Danmark handlingsplan for vedvarende energi \\
\hline 7. United Kingdom & 3 & 3 & UK renewable energy action plan \\
\hline 8. Estonia & 4 & 2 & Eesti taastuvenergia tegevuskava \\
\hline 9. Finland & 4 & 2 & Suomi uusiutuvaa energiaa koskeva toimintasuunnitelma \\
\hline 10. France & 4 & 2 & France plan d'action en faveur des énergies renouvelables \\
\hline 11. Greece & 2 & - & 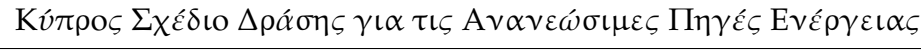 \\
\hline 12. Netherlands & 3 & 2 & Holland actieplan hernieuwbare energie \\
\hline 13. Croatia & 2 & 2 & Hravatska akcijski plan obnovljivih izvora energije \\
\hline \multirow{2}{*}{ 14. Ireland } & \multirow{2}{*}{3} & 3 & Ireland renewable energy action plan \\
\hline & & 2 & Éire plean gníomhaíochta fuinnimh in-athnuaite náisiúnta \\
\hline 15. Poland & 3 & 2 & Polska plan działania w zakresie energii odnawialnej \\
\hline 16. Latvia & 3 & 2 & Latvija atjaunojamās energijas rīcības plāns \\
\hline 17. Lithuania & 3 & 2 & Lietuva atjaunojamās enerǵijas rīcības plāns \\
\hline \multirow{2}{*}{ 18. Luxembourg } & \multirow{2}{*}{4} & - & lëtzebuerger erneierbarer Energie Aktiounsplang \\
\hline & & 3 & Luxemburg Aktionsplan für erneuerbare Energien \\
\hline 19. Hungary & 2 & 2 & Hungary renewable energy action plan \\
\hline
\end{tabular}


Table 2. Cont

\begin{tabular}{|c|c|c|c|}
\hline Country & Clicks English & Clicks Official/Further Language & $\begin{array}{c}\text { Search Terms in National Languages } \\
\text { /Name of Country + Renewable Energy Action Plan/ }\end{array}$ \\
\hline 20. Malta & 2 & - & Malta pjan ta 'azzjoni ghall-energija rinnovabbli \\
\hline 21. Germany & 3 & 2 & Deutschland Aktionsplan für erneuerbare Energien \\
\hline 22. Italy & 3 & 2 & Italia piano d'azione per le energie rinnovabili \\
\hline 23. Portugal & 3 & 2 & Portugal plano de ação para energias renováveis \\
\hline 24. Romania & 2 & 6 & România plan de acțiune pentru energie regenerabilă \\
\hline 25. Spain & 3 & 3 & España plan de acción de energías renovables \\
\hline 26. Sweden & 3 & 2 & Sverige handlingsplan för förnybar energi \\
\hline 27. Slovakia & 3 & 2 & Slovensko akčný plán pre obnovitel'né zdroje energie \\
\hline 28. Slovenia & 2 & 3 & Slovenija akcijski načrt za obnovljivo energijo \\
\hline 29. Directive 2009/28/EC (summary) & 2 & 3 & In the 24 official languages of the EU \\
\hline 30. Directive 2009/28/EC (full text) & 3 & 4 & In 23 official languages of the EU (no Irish) \\
\hline
\end{tabular}

Source: the authors' own work 


\subsection{Results of the Readability Tests}

In the course of the readability tests of the samples from the 28 member states we examined a collection of texts of 79,604 words in total. Their lengths varied from 408 (Luxembourg) to 7244 words (Romania).

Microsoft Word's readability statistics provided us with 10 types of data about each text:

- the number of words;

- the number of characters;

- the number of paragraphs;

- the number of sentences;

- the average number of sentences per paragraph;

- the average number of words per sentence;

- the average number of characters per word;

- the percentage of passive sentences in the whole text;

- $\quad$ the Flesch Reading Ease score;

- the Flesch-Kincaid Grade Level.

After the examinations we tested how the results of the two readability tests related to each other. The comparison of the Flesch and Flesch-Kincaid readability tests showed a very strong correlation $\left(\mathrm{R}^{2}=0.904\right)$ (Table A1).

As regards the readability of the samples, it can be concluded that all the analyses run delivered results which seemed realistic, with one exception, and provided a suitable basis for further investigation. Only the Latvian sample gave a Flesch readability score of 0.0, but its Flesch-Kincaid grade level (24.3) also indicated a text which was extremely difficult to read. Moreover, the average number of words per sentence had an extremely high value (42.4) too, which was obviously the main cause of the bad readability results. Rechecking the sample, it could be established that the text could indeed be characterised by the great length of its sentences.

Concerning all the samples, the Flesch reading ease scores ranged from 0.0 to 39.9. According to Rudolf Flesch's interpretation [49], scores between 0.0 and 30.0 indicate texts that are very difficult to read and their comprehension requires at least a university degree. The values ranging from 30.00 to 50.00 signal the difficult-to-read category. To be able to understand texts in this it is "enough to be an undergraduate". According to the results of the tests, 26 out of the 28 samples (93\%) fell into the very difficult category, while only two (7\%), those of the United Kingdom and Finland, reached the slightly easier difficult level.

The Flesch-Kincaid readability values, correlating with the above scores, as seen before, also showed difficult readability, with grade levels from 12.7 to 24.3. This means that without tertiary studies one does not have much chance of understanding the texts, and what is more, in the case of 5 out of the 28 samples (17.86\%) even 20 years of education would not be enough.

Table 3 shows the results of the two types of tests together. The ordinal numbers show the order of reading ease from easier to more difficult (except for equal values, marked yellow). The easiest 10 samples are highlighted in green, while the most difficult 10 are in red. Comparing the two lists, the most discrepancies can be seen in the middle (white) section, e.g., Estonia is 16th in the first table, but it is only 22nd in the second one (marked blue).

After this, we compared the data delivered by the tests to the power distance values of the countries based on Hofstede's research [50]. Our hypothesis was that the two kinds of values were related to each other. It was assumed that the action plans, which were all results of team work, and although the European Commission decision stipulated what and how they had to contain, differed from each other, reflecting the cultures that they were the products of. The assumption concerning the translations was that they were the works of professional translators who were able not only to convey the precise meaning of the original texts but also managed to preserve their other characteristics in 
their translations. This had to mean that the readability and comprehensibility of the English texts also reflected the readability of the source language texts.

Table 3. The 28 samples in order of reading ease, from easiest to more difficult, according to the two testing methods.

\begin{tabular}{|c|c|c|c|c|c|}
\hline Ranking & Country & Flesch & Country & Flesch-Kincaid & Ranking \\
\hline 1 & $\begin{array}{l}\text { United } \\
\text { Kingdom }\end{array}$ & 39.9 & $\begin{array}{l}\text { United } \\
\text { Kingdom }\end{array}$ & 12.7 & 1 \\
\hline 2 & Finland & 38.1 & Finland & 13.9 & 2 \\
\hline 3 & Slovakia & 25.5 & Cyprus & 14.9 & 3 \\
\hline 4 & Malta & 22.5 & Netherlands & 15.0 & 4 \\
\hline 5 & Netherlands & 21.4 & Malta & 15.2 & 5 \\
\hline 6 & Belgium & 19.3 & Belgium & 15.5 & 6 \\
\hline 7 & Austria & 18.5 & Slovakia & 15.6 & 8 \\
\hline 8 & Luxembourg & 17.7 & Austria & 15.6 & 7 \\
\hline 9 & Cyprus & 16.8 & Luxembourg & 16.1 & 9 \\
\hline 10 & Denmark & 16.2 & Germany & 17.3 & 10 \\
\hline 11 & Germany & 14.6 & Romania & 17.6 & 11 \\
\hline 12 & Lithuania & 13.6 & Denmark & 17.7 & 12 \\
\hline 13 & Bulgaria & 13.5 & Lithuania & 17.9 & 14 \\
\hline 14 & Hungary & 13.5 & Czech Republic & 17.9 & 13 \\
\hline 15 & Czech Republic & 13.4 & Spain & 18.5 & 15 \\
\hline 16 & Estonia & 12.1 & Sweden & 18.6 & 16 \\
\hline 17 & Romania & 11.4 & Bulgaria & 18.7 & 17 \\
\hline 18 & Spain & 10.8 & France & 18.8 & 18 \\
\hline 19 & Sweden & 10.3 & Ireland & 18.8 & 19 \\
\hline 20 & France & 7.9 & Hungary & 19.5 & 20 \\
\hline 21 & Ireland & 7.3 & Italy & 19.7 & 21 \\
\hline 22 & Greece & 6.7 & Estonia & 19.8 & 22 \\
\hline 23 & Italy & 6.2 & Slovenia & 19.9 & 23 \\
\hline 24 & Slovenia & 6.1 & Greece & 21.2 & 24 \\
\hline 25 & Croatia & 4.3 & Croatia & 21.3 & 25 \\
\hline 26 & Portugal & 3.6 & Poland & 21.3 & 26 \\
\hline 27 & Poland & 1.3 & Portugal & 21.8 & 27 \\
\hline 28 & Latvia & 0.0 & Latvia & 24.3 & 28 \\
\hline
\end{tabular}

Source: the authors' own work.

As seen earlier, Loughran and McDonald's [32] research demonstrated that the readability of the texts they examined was related to the level of democracy of the management of the organisations that had produced them. In addition, they also showed that the companies could expect greater success among their clients if their written communication was easier to understand. In simpler terms, this means that according to their findings a more democratic management style (characteristic of lower power distance) means writing in a more comprehensible way, which will result in more successful communication.

The countries were first listed according to their Flesch reading ease scores, from the easiest to the more difficult ones, marking the ten easiest samples in green and the most difficult ten in red. (Certain values occurred in the case of more than one sample.) Then, the same was done for the Flesch-Kincaid grade levels and Hofstede's power distance values [50]. In this part of the research Cyprus had to be omitted because no power distance data were available for it. Table 4, thusly prepared, can be seen below. The equal values are marked yellow.

The next table (Table 5), which combines the three lists, shows the same data in order of the power distance values of the specific countries. 
Table 4. Ranking on the bases of the Flesch Reading Ease Scores, the Flesch-Kincaid grade levels, and the power distance values.

\begin{tabular}{|c|c|c|c|c|c|c|c|c|}
\hline 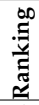 & Country & Flesch & 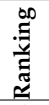 & Country & Flesch-Kincaid & 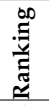 & Country & Power Distance \\
\hline 1 & United Kingdom & 39.9 & $\overline{1}$ & United Kingdom & 12.7 & 1 & Austria & 11 \\
\hline 2 & Finland & 38.1 & 2 & Finland & 13.9 & 2 & Denmark & 18 \\
\hline 3 & Slovakia & 25.5 & 3 & Netherlands & 15 & 3 & Ireland & 28 \\
\hline 4 & Malta & 22.5 & 4 & Malta & 15.2 & 4 & Sweden & 31 \\
\hline 5 & Netherlands & 21.4 & 5 & Belgium & 15.5 & 5 & Finland & 33 \\
\hline 6 & Belgium & 19.3 & 6 & Slovakia & 15.6 & 6 & Germany & 35 \\
\hline 7 & Austria & 18.5 & 7 & Austria & 15.6 & 7 & United Kingdom & 35 \\
\hline 8 & Luxembourg & 17.7 & 8 & Luxembourg & 16.1 & 8 & Netherlands & 38 \\
\hline 9 & Denmark & 16.2 & 9 & Germany & 17.3 & 9 & Luxembourg & 40 \\
\hline 10 & Germany & 14.6 & 10 & Romania & 17.6 & 10 & Estonia & 40 \\
\hline 11 & Lithuania & 13.6 & 11 & Denmark & 17.7 & 11 & Lithuania & 42 \\
\hline 12 & Hungary & 13.5 & 12 & Lithuania & 17.9 & 12 & Latvia & 44 \\
\hline 13 & Bulgaria & 13.5 & 13 & Czech Republic & 17.9 & 13 & Hungary & 46 \\
\hline 14 & Czech Republic & 13.4 & 14 & Spain & 18.5 & 14 & Italy & 50 \\
\hline 15 & Estonia & 12.1 & 15 & Sweden & 18.6 & 15 & Malta & 56 \\
\hline 16 & Romania & 11.4 & 16 & Bulgaria & 18.7 & 16 & Spain & 57 \\
\hline 17 & Spain & 10.8 & 17 & France & 18.8 & 17 & Czech Republic & 57 \\
\hline 18 & Sweden & 10.3 & 18 & Ireland & 18.8 & 18 & Greece & 60 \\
\hline 19 & France & 7.9 & 19 & Hungary & 19.5 & 19 & Portugal & 63 \\
\hline 20 & Ireland & 7.3 & 20 & Italy & 19.7 & 20 & Belgium & 65 \\
\hline 21 & Greece & 6.7 & 21 & Estonia & 19.8 & 21 & France & 68 \\
\hline 22 & Italy & 6.2 & 22 & Slovenia & 19.9 & 22 & Poland & 68 \\
\hline 23 & Slovenia & 6.1 & 23 & Greece & 21.2 & 23 & Bulgaria & 70 \\
\hline 24 & Croatia & 4.3 & 24 & Croatia & 21.3 & 24 & Slovenia & 71 \\
\hline 25 & Portugal & 3.6 & 25 & Poland & 21.3 & 25 & Croatia & 73 \\
\hline 26 & Poland & 1.3 & 26 & Portugal & 21.8 & 26 & Romania & 90 \\
\hline 27 & Latvia & 0.0 & 27 & Latvia & 24.3 & 27 & Slovakia & 104 \\
\hline
\end{tabular}

Source: the authors' own work.

Table 5. The combined Flesch Reading Ease Scores, the Flesch-Kincaid grade levels, and the power distance values in the order of the power distance from low to high.

\begin{tabular}{|c|c|c|c|c|}
\hline Ranking & Country & Power Distance & Flesch & Flesch-Kincaid \\
\hline 1 & Austria & 11 & 18.5 & 15.6 \\
\hline 2 & Denmark & 18 & 16.2 & 17.7 \\
\hline 3 & Ireland & 28 & 7.3 & 18.8 \\
\hline 4 & Sweden & 31 & 10.3 & 18.6 \\
\hline 5 & Finland & 33 & 38.1 & 13.9 \\
\hline 6 & United Kingdom & 35 & 39.9 & 12.7 \\
\hline 7 & Germany & 35 & 14.6 & 17.3 \\
\hline 8 & Netherlands & 38 & 21.4 & 15 \\
\hline 9 & Estonia & 40 & 12.1 & 19.8 \\
\hline 10 & Luxembourg & 40 & 17.7 & 16.1 \\
\hline 11 & Lithuania & 42 & 13.6 & 17.9 \\
\hline 12 & Latvia & 44 & 0.0 & 24.3 \\
\hline 13 & Hungary & 46 & 13.5 & 19.5 \\
\hline 14 & Italy & 50 & 6.2 & 19.7 \\
\hline 15 & Malta & 56 & 22.5 & 15.2 \\
\hline 16 & Czech Republic & 57 & 13.4 & 17.9 \\
\hline 17 & Spain & 57 & 10.8 & 18.5 \\
\hline 18 & Greece & 60 & 6.7 & 21.2 \\
\hline 19 & Portugal & 63 & 3.6 & 21.8 \\
\hline 20 & Belgium & 65 & 19.3 & 15.5 \\
\hline 21 & France & 68 & 7.9 & 18.8 \\
\hline 22 & Poland & 68 & 1.3 & 21.3 \\
\hline 23 & Bulgaria & 70 & 13.5 & 18.7 \\
\hline 24 & Slovenia & 71 & 6.1 & 19.9 \\
\hline 25 & Croatia & 73 & 4.3 & 21.3 \\
\hline 26 & Romania & 90 & 11.4 & 17.6 \\
\hline 27 & Slovakia & 104 & 25.5 & 15.6 \\
\hline
\end{tabular}

Source: the authors' own work. 
In order to verify the validity of the hypothesis that there is a connection between the power distance and the readability values, correlation and regression analyses were carried out, in the course of which polynomial regression produced the closest fit (Table A2) and the following results, displayed in Table 6, were received.

Table 6. The results of the correlation analyses between the power distance values and the readability scores.

\begin{tabular}{cccc}
\hline Relationship & $\mathbf{R}^{\mathbf{2}}$ & $\mathbf{F}$ & $p$-Value \\
\hline Power distance-Flesch index & 0.136 & 1.896 & 0.172 \\
\hline Power distance-Flesch-Kincaid index & 0.163 & 2.333 & 0.119 \\
\hline \multicolumn{4}{c}{ Source: the authors' own work }
\end{tabular}

Source: the authors' own work.

It can be established that regarding the entirety of the samples the significant relationship was very weak between the power distance and the readability values.

The same analyses were also performed regarding the 2017 real GDP per capita [51], HDI [52] and research and development (R\&D) expenditure (\% of GDP) [53] data of the member states examined with the following results, shown in Table 7.

Table 7. The results of the correlation analyses between the GDP, HDI, and R\&D expenditure (\% of GDP) values and the readability scores.

\begin{tabular}{cccc}
\hline Relationship & $\mathbf{R}^{\mathbf{2}}$ & $\mathbf{F}$ & $\boldsymbol{p}$-Value \\
\hline GDP-Flesch index & 0.140 & 1.951 & 0.164 \\
\hline GDP-Flesch-Kincaid index & 0.256 & 4.138 & 0.029 \\
\hline HDI-Flesch index & 0.152 & 2.145 & 0.139 \\
\hline HDI-Flesch-Kincaid index & 0.263 & 4.277 & 0.026 \\
\hline R\&D-Flesch index & 0.097 & 1.292 & 0.293 \\
\hline R\&D-Flesch-Kincaid index & 0.147 & 2.074 & 0.148 \\
\hline
\end{tabular}

Source: the authors' own work.

In the case of the GDP data and the Flesch-Kincaid indices and that of the HDI data and the Flesch-Kincaid indices only medium relationships were shown.

Then, the samples were divided into quartiles according to their power distance values after Slovakia had been assigned a value of 25 on the basis of Bašnáková, Brezina, and Masaryk's research [54], and a pattern emerged, revealing that with the exception of Belgium, all the remaining countries' samples in the last quartile had worse than average Flesch reading ease scores (13.915). Thus, it seemed reasonable to revisit the countries in the last quartile, which was based on Hofstede's power distance values. It is, however, also worth noting that Belgium's situation is special because among the power distance data given by [50] the authors assigned two values to Belgium: one to the French (68) and one to the Flemish speaking part (61) of the country. The value (65) used in this research was the average of the two. Because of this uncertainty of the Belgian value it was decided that Belgium had to be removed from among the samples examined. The EU countries divided into quartiles according to their power distance values are shown in Table 8, below. 
Table 8. The list of the member states of the European Union divided into quartiles according to Hofstede's power distance values, with Slovakia's modified value suggested by Bašnáková, Brezina, and Masaryk [54].

\begin{tabular}{|c|c|c|c|c|c|c|c|}
\hline Rank & Country & $\begin{array}{c}\text { Power } \\
\text { Distance }\end{array}$ & $\begin{array}{l}\text { Real GDP } \\
\text { Per Capita }\end{array}$ & $\begin{array}{l}\text { R\&D Exp } \\
\% \text { of GDP }\end{array}$ & HDI & $\begin{array}{l}\text { Flesch } \\
\text { Index }\end{array}$ & $\begin{array}{l}\text { Flesch-Kincaid } \\
\text { Index }\end{array}$ \\
\hline 1 & Austria & 11 & 37,100 & 3.16 & 0.908 & 18.5 & 15.6 \\
\hline 2 & Denmark & 18 & 47,100 & 3.05 & 0.929 & 16.2 & 17.7 \\
\hline 3 & Slovakia & 25 & 15,000 & 0.88 & 0.855 & 25.5 & 15.6 \\
\hline 4 & Ireland & 28 & 54,200 & 1.05 & 0.938 & 7.3 & 18.8 \\
\hline 5 & Sweden & 31 & 43,400 & 3.04 & 0.933 & 10.3 & 18.6 \\
\hline 6 & Finland & 33 & 36,000 & 2.76 & 0.92 & 38.1 & 13.9 \\
\hline 7 & $\begin{array}{l}\text { United } \\
\text { Kingdom }\end{array}$ & 35 & 32,200 & 1.66 & 0.922 & 39.9 & 12.7 \\
\hline 8 & Germany & 35 & 35,400 & 3.02 & 0.936 & 14.6 & 17.3 \\
\hline 9 & Netherlands & 38 & 40,700 & 1.99 & 0.933 & 21.4 & 15.0 \\
\hline 10 & Luxembourg & 40 & 80,300 & 1.26 & 0.904 & 17.7 & 16.1 \\
\hline 11 & Estonia & 40 & 14,400 & 1.29 & 0.871 & 12.1 & 19.8 \\
\hline 12 & Lithuania & 42 & 12,700 & 0.89 & 0.858 & 13.6 & 17.9 \\
\hline 13 & Latvia & 44 & 11,600 & 0.51 & 0.847 & 0.0 & 24.3 \\
\hline 14 & Hungary & 46 & 11,800 & 1.35 & 0.838 & 13.5 & 19.5 \\
\hline 15 & Italy & 50 & 26,500 & 1.35 & 0.88 & 6.2 & 19.7 \\
\hline 16 & Malta & 56 & 20,800 & 0.54 & 0.878 & 22.5 & 15.2 \\
\hline 17 & Czech Republic & 57 & 17,200 & 1.79 & 0.888 & 13.4 & 17.9 \\
\hline 18 & Spain & 57 & 24,400 & 1.2 & 0.891 & 10.8 & 18.5 \\
\hline 19 & Greece & 60 & 17,400 & 1.13 & 0.87 & 6.7 & 21.2 \\
\hline 20 & Portugal & 63 & 17,500 & 1.33 & 0.847 & 3.6 & 21.8 \\
\hline 21 & Belgium & 65 & 35,000 & 2.58 & 0.916 & 19.3 & 15.5 \\
\hline 22 & France & 68 & 32,400 & 2.19 & 0.901 & 7.9 & 18.8 \\
\hline 23 & Poland & 68 & 11,800 & 1.03 & 0.865 & 1.3 & 21.3 \\
\hline 24 & Bulgaria & 70 & 6300 & 0.75 & 0.813 & 13.5 & 18.7 \\
\hline 25 & Slovenia & 71 & 19,400 & 1.86 & 0.896 & 6.1 & 19.9 \\
\hline 26 & Croatia & 73 & 11,500 & 0.86 & 0.831 & 4.3 & 21.3 \\
\hline 27 & Romania & 90 & 8300 & 0.5 & 0.811 & 11.4 & 17.6 \\
\hline
\end{tabular}

For the thusly formed group, which showed similar characteristics, we once again carried out the polynomial regression analyses (Table A3), whose summarised results can be seen in Table 9, as follows.

Table 9. The results of the correlation analyses between the GDP, power distance, HDI, and R\&D (\% of GDP) values of the countries in the last quartile of the list of EU countries ranked according to their power distance values and the readability scores.

\begin{tabular}{cccc}
\hline Relationship & $\mathbf{R}^{\mathbf{2}}$ & $\mathbf{F}$ & $p$ Value \\
\hline GDP-Flesch index & 0.546 & 1.801 & 0.306 \\
\hline GDP- Flesch-Kincaid index & 0.412 & 1.053 & 0.450 \\
\hline Power distance-Flesch index & 0.181 & 0.332 & 0.741 \\
\hline Power distance-Flesch-Kincaid index & 0.46 & 1.277 & 0.397 \\
\hline HDI-Flesch index & 0.945 & 25.743 & 0.013 \\
\hline HDI-Flesch-Kincaid index & 0.894 & 12.717 & 0.034 \\
\hline R\&D-Flesch index & 0.513 & 1.578 & 0.340 \\
\hline R\&D-Flesch-Kincaid index & 0.775 & 0.152 & 0.107 \\
\hline
\end{tabular}

Source: the authors' own work. 
What is shown by the results is that the relationships between the GDP per capita, the power distance indices, and the R\&D (\% of GDP) data and the results delivered by either of the readability tests were not significant, while in the case of the HDI values strong significant relationships were indicated with both readability indices.

Besides the results presented above, the examinations performed also highlighted some limitations. On the one hand, it seems that the power distance values associated with Hofstede's research may not always be completely reliable, for example, in the case of Slovakia and Belgium. On the other hand, it would also be of great benefit if readability formulas and/or methods adapted to the languages of the examined countries were also available. That way, texts in the national languages meant for the citizens of the given countries could be examined, and the corpus could also be expanded to include a wider variety of texts written for the promotion of the use of renewable energy.

\section{Conclusions}

Concerning the online availability of the examined documents it can be concluded that they can be easily accessed in most cases in the national languages of the EU member states, as well as in English. However, a less welcome result of the research showed that EU residents with mother tongues other than their countries' official languages (sometimes even with a mother tongue that is one of the official languages of a bi- or multilingual state) may not always access these texts in their native languages, and certain important webpages of the European Commission can only be read in English.

Regarding the readability tests, one of the important outcomes of the comparisons was that it was shown that there is a strong correlation between the results of the two readability index calculation methods.

The data obtained also indicated that without exception the renewable energy action plans of all the 28 member states were hard to read; only those of Finland and the United Kingdom proved to be slightly less difficult. This means that although according to the results of the accessibility test the documents were easily available online, reading and interpreting them may cause difficulties for the average reader. Thus, it is questionable to what extent the right of information is realised regarding the entire population.

According to the calculations carried out for the whole of the sample, no significant relationship was detected between Hofstede's power distance indices and the Flesch and Flesch-Kincaid readability scores delivered by the tests of the countries' text samples. In the case of the GDP data and the Flesch-Kincaid indices and that of the HDI data and the Flesch-Kincaid indices only medium relationships were shown.

The HDI figures of the countries and the scores produced by both readability assessment methods indicated strong relationships in the last quartile of the list of EU countries ranked according to their power distance values. Based on this, it may be assumed that education and the level of schooling is a determining factor concerning the readability of the texts.

The research delivered interesting results regarding the very high power distance value of Slovakia. It turned out that the raw value of 79 established on the basis of the survey conducted by Kolman et al. in 2003, which was later recalibrated to 103 [55], then modified by Hofstede to 104 by estimate [54], did not fit the pattern that took shape in this research. The examination of the Slovakian sample produced results that were similar to those of the countries with lower power distance figures, both in the Flesch and the Flesch-Kincaid readability tests. This was also supported by the fact that in the regression analysis, results indicating stronger relationships were obtained when Slovakia's power distance index of 104 was replaced by 25, according to Bašnáková, Brezina, and Masaryk [54]. This suggests that concerning the aspects examined herein it is probably more appropriate if, in the case of Slovakia, the value recommended by Bašnáková, Brezina, and Masaryk [54] is used. 
Author Contributions: A.V. conceived, designed, and performed the experiments. All authors have read and agreed to the published version of the manuscript.

Acknowledgments: The work/publication is supported by the EFOP-3.6.3-VEKOP-16-2017-00008 project. The project is co-financed by the European Union and the European Social Fund. The authors have worked together with the KRAFT Social Innovation Lab of the Institute of Advanced Studies Köszeg (IASK).

Conflicts of Interest: The authors declare no conflict of interest.

\section{Abbreviations}

The following abbreviations are used in this manuscript:

ASL average sentence length

ASW average number of syllables per word

EU European Union

GDP gross domestic product

HDI Human Development Index

NGOs non-governmental organizations

R\&D research and development

RES renewable energy sources

UN United Nations

UNFCCC United Nations Framework Convention on Climate Change

VAT value-added tax

\section{Appendix A}

Table A1. The result and the parameters of the regression function obtained by the correlation analysis of the results of the Flesch and Flesch-Kincaid readability tests.

\begin{tabular}{cccccc}
\hline $\mathbf{R}^{\mathbf{2}}$ & $\mathbf{F}$ & $\boldsymbol{p}$ Value & Constant $^{*}$ & $\mathbf{b 1}{ }^{* *}$ & $\mathbf{b 2}^{* * *}$ \\
\hline $\mathbf{0 . 9 0 4}$ & 113.652 & $\mathbf{0 . 0 0 0}$ & 23.003 & -0.457 & 0.005 \\
\hline \multicolumn{6}{c}{ Note: ${ }^{*} p$ value $=0.000^{* *} p$ value $=0.000^{* * *} p$ value $=0.000}$.
\end{tabular}

Table A2. The parameters of the regression functions obtained by the correlation analyses of the power distance values and the results of the Flesch and Flesch-Kincaid readability tests.

\begin{tabular}{cccc}
\hline Denomination & Constant & b1 & b2 \\
\hline & Power distance-Flesch index & \\
\hline parameters & 31.528 & -0.626 & 0.005 \\
\hline$p$ value & 0.002 & 0.084 & 0.131 \\
\hline parameters & Power distance-Flesch-Kincaid index & \\
\hline$p$ value & 12.829 & 0.194 & -0.002 \\
\hline
\end{tabular}


Table A3. The parameters of the regression functions obtained by the correlation analyses between the readability scores and the GDP, the power distance, the HDI and R\&D (\% of GDP) values of the countries in the last quartile of the list of EU countries ranked according to their power distance values.

\begin{tabular}{|c|c|c|c|}
\hline Denomination & Constant & b1 & b2 \\
\hline \multicolumn{4}{|c|}{ GDP-Flesch index } \\
\hline parameters & 22.294 & -0.002 & 0.0000005 \\
\hline$p$ value & 0.069 & 0.156 & 0.167 \\
\hline \multicolumn{4}{|c|}{ GDP- Flesch-Kincaid index } \\
\hline parameters & 15.646 & 0.001 & -0.000000001 \\
\hline$p$ value & 0.014 & 0.253 & 0.253 \\
\hline \multicolumn{4}{|c|}{ Power distance-Flesch index } \\
\hline parameters & 19.537 & -0.510 & 0.005 \\
\hline$p$ value & 0.965 & 0.965 & 0.949 \\
\hline \multicolumn{4}{|c|}{ Power distance-Flesch-Kincaid index } \\
\hline parameters & -66.451 & 2.291 & -0.015 \\
\hline$p$ value & 0.940 & 0.481 & 0.463 \\
\hline \multicolumn{4}{|c|}{ HDI-Flesch index } \\
\hline parameters & 3431.558 & -7962.878 & 4620.487 \\
\hline$p$ value & 0.008 & 0.008 & 0.009 \\
\hline \multicolumn{4}{|c|}{ HDI-Flesch-Kincaid index } \\
\hline parameters & -1211.267 & 2872.660 & -1672.928 \\
\hline$p$ value & 0.017 & 0.017 & 0.017 \\
\hline \multicolumn{4}{|c|}{ R\&D-Flesch index } \\
\hline parameters & 26.964 & -34.189 & 11.826 \\
\hline$p$ value & 0.094 & 0.181 & 0.195 \\
\hline \multicolumn{4}{|c|}{ R\&D-Flesch Kincaid index } \\
\hline parameters & 11.777 & 14.325 & -5.158 \\
\hline$p$ value & 0.02 & 0.05 & 0.05 \\
\hline
\end{tabular}

\section{References}

1. Nagy, D.; Balogh, P.; Gabnai, Z.; Popp, J.; Oláh, J.; Bai, A. Economic Analysis of Pellet Production in Co-Digestion Biogas Plants. Energies 2018, 11, 1135. [CrossRef]

2. International Renewable Energy Agency IRENA; International Energy Agency (IEA); Renewable Energy Policy Network for the 21st Century. Renewable Energy Policies in a Time of Transition. Available online: https://www.irena.org/-/media/Files/IRENA/Agency/Publication/2018/Apr/IRENA_IEA_ REN21_Policies_2018.pdf (accessed on 20 January 2020).

3. Helm, D. The European framework for energy and climate policies. Energy Policy 2014, 64, 29-35. [CrossRef]

4. BP p.l.c. BP Statistical Review of World Energy 2019, 68th Edition. Available online: https:/www.bp.com/content/dam/bp/business-sites/en/global/corporate/pdfs/energy-economics/ statistical-review/bp-stats-review-2019-full-report.pdf (accessed on 20 January 2020).

5. Kaszás, N.; Keller, K.; Birkner, Z. The Role of Transferring Knowledge in Case of Non-Business Sector Projects. Procedia Soc. Behav. Sci. 2016, 221, 226-235. [CrossRef]

6. Schmalensee, R. Evaluating Policies to Increase Electricity Generation from Renewable Energy. Rev. Environ. Econ. Policy. 2012, 6, 45-64. [CrossRef] 
7. Renewables 2018 Global Status Report-REN21. Available online: https:/www.ren21.net/wp-content/ uploads/2019/05/GSR2018_Full-Report_English.pdf (accessed on 29 January 2020).

8. Edenhofer, O.; Hirth, L.; Knopf, B.; Pahle, M.; Schlömer, S.; Schmid, E.; Ueckerdt, F. On the economics of renewable energy sources. Energy Econ. 2013, 40, S12-S23. [CrossRef]

9. United Nations Framework Convention on Climate Change. The Paris Agreement. Available online: https: //unfccc.int/process-and-meetings/the-paris-agreement/the-paris-agreement (accessed on 10 December 2019).

10. Džananović, E.; Dacić-Lepara, S. The Relationship Between GDP and Electricity Consumption in Southeast European Countries. Available online: https://link.springer.com/chapter/10.1007/978-3-319-47295-9_17 (accessed on 29 January 2020).

11. Kasperowicz, R. Electricity consumption and economic growth: Evidence from Poland. J. Int. Stud. 2014, 7, 46-57. [CrossRef]

12. Kiss, I.; Reith, A. Architectural and urban design tools for reducing energy consumption in cities. Pollack Period. 2013, 8, 151-161. [CrossRef]

13. Delbeke, J.; Vis, P. EU Climate Policy Explained; Routledge Publisher: Brussels, Belgium, 2016.

14. Kalkuhl, M.; Edenhofer, O.; Lessmann, K. Renewable Energy Subsidies: Second-Best Policy or Fatal Aberration for Mitigation? SSRN Electron. J. 2012, 48, 1-32. [CrossRef]

15. Parry, I. Designing Fiscal Policy to Address the External Costs of Energy. Int. Rev. Environ. Resour. Econ. 2015, 8, 1-56. [CrossRef]

16. Morata, F.; Solorio Sandoval, I. European Energy Policy: An Environmental Approach; Edward Elgar: Cheltenham, UK, 2012; ISBN 0857939203.

17. Skjærseth, J.B. Linking EU climate and energy policies: Policy-making, implementation and reform. Int. Environ. Agreements Polit. Law Econ. 2016, 16, 509-523. [CrossRef]

18. Torok, A.; Zoldy, M. Energetic and economical investigation of greenhouse gas emission of Hungarian road transport sector. Pollack Period. 2010, 5, 123-132. [CrossRef]

19. EUR-Lex. Directive 2009/28/EC of the European Parliament and of the Council of 23 April 2009 on the Promotion of the Use of Energy from Renewable Sources and Amending and Subsequently Repealing Directives 2001/77/EC and 2003/30/EC. Available online: http://www.nezeh.eu/assets/media/fckuploads/file/ Legislation/RED_23April2009.pdf (accessed on 10 December 2019).

20. Lerum Boasson, E.; Wettestad, J. EU Climate Policy Industry, Policy Interaction and External Environment; Routledge: Farnham, UK; Burlington, VT, USA, 2013.

21. Del Río, P.; Mir-Artigues, P. Combinations of support instruments for renewable electricity in Europe: A review. Renew. Sustain. Energy Rev. 2014, 40, 287-295. [CrossRef]

22. Solorio, I.; Jörgens, H. A Guide to EU Renewable Energy Policy; Edward Elgar Publishing: Cheltenham Glos, UK, 2017.

23. European Commission. COMMUNICATION FROM THE COMMISSION TO THE EUROPEAN PARLIAMENT, THE COUNCIL, THE EUROPEAN ECONOMIC AND SOCIAL COMMITTEE, THE COMMITTEE OF THE REGIONS AND THE EUROPEAN INVESTMENT BANK. Available online: https:/ec.europa.eu/energy/sites/ener/files/documents/com_860_final.pdf (accessed on 16 December 2019).

24. Ringel, M.; Knodt, M. The governance of the European Energy Union: Efficiency, effectiveness and acceptance of the Winter Package 2016. Energy Policy 2018, 112, 209-220. [CrossRef]

25. Rogers, J.C.; Simmons, E.A.; Convery, I.; Weatherall, A. Public perceptions of opportunities for community-based renewable energy projects. Energy Policy 2008, 36, 4217-4226. [CrossRef]

26. Rogers, J.C.; Simmons, E.A.; Convery, I.; Weatherall, A. Social impacts of community renewable energy projects: Findings from a woodfuel case study. Energy Policy 2012, 42, 239-247. [CrossRef]

27. Donovan, R.; Henley, N. Principles and Practice of Social Marketing: An International Perspective; Cambridge University Press: Cambridge, UK, 2010; ISBN 9780511761751.

28. Tonelli, S.; Tran Manh, K.; Pianta, E. Making Readability Indices Readable. In Proceedings of the First Workshop on Predicting and Improving Text Readability for Target Reader Populations, Montréal, QC, Canada, 7 July 2012.

29. Dubay, W.H. The Principles of Readability. Available online: https:/files.eric.ed.gov/fulltext/ED490073.pdf (accessed on 16 December 2019). 
30. Dale, E.; Chall, J.S. The Concept of Readability. Elem. English 1949, 26, 19-26.

31. Stockmeyer, N.O. Using Microsoft Word's Readability Program. Mich. Bar J. 2009, 88, 46.

32. Loughran, T.; McDonald, B. Measuring Readability in Financial Text. Available online: https://pdfs. semanticscholar.org/23ed/e2565ca529039a700742d7bf1e75c9162b2f.pdf (accessed on 16 December 2019).

33. Zakaluk, B.L.; Samuels, S.J.; International Reading Association. Readability: Its Past, Present, and Future; International Reading Association: Newark, DE, USA, 1988; ISBN 9780872077959.

34. Kugler, N.; Tolcsvai Nagy, G. Nyelvi Fogalmak Kisszótára A-Zs-Dictionary of Language Concepts A-Zs; KORONA KIADÓ KFT:: Budapest, Hungary, 2000.

35. Krippendorff, K. A Tartalomelemzés Módszertanának Alapjai-Basics of Content Analysis Methodology; Balassi: Budapest, Hungary, 1995; ISBN 9637873805.

36. Commission Decision of 30 June 2009 Establishing a Template for National Renewable Energy Action Plans under Directive 2009/28/EC of the European Parliament and of the Council (Notified under Document Number C(2009) 5174) (Text with EEA Relevance). Available online: https://eur-lex.europa.eu/legal-content/ EN/TXT/?uri=CELEX\%3A32009D0548 (accessed on 10 December 2019).

37. Ződi, Z. Jogi szövegtípusok—Legal text types. Magy. Jogi Nyelv 2017, 2, 20-29.

38. Hováth, Z. Kézikönyv az Európai Unióról-Handbook on the European Union, 8th ed.; HVG-ORAC Lap-és Könyvkiadó Kft.: Budapest, Hungary, 2011; ISBN 978-963-258-129-3.

39. Eurostat. Digital Economy and Society Statistics-Households and Individuals, Statistics Explained. Available online: https:/ec.europa.eu/eurostat/statistics-explained/pdfscache/33472.pdf (accessed on 16 December 2019).

40. StatCounter. Search Engine Market Share Europe. Available online: https://gs.statcounter.com/search-enginemarket-share/all/europe (accessed on 10 December 2019).

41. Zhou, S.; Jeong, H.; Green, P.A. How consistent are the best-known readability equations in estimating the readability of design standards? IEEE Trans. Prof. Commun. 2017, 60, 97-111. [CrossRef]

42. Flesch, R. The Art of Readable Writing; The Associated Press: New York, NY, USA, 1949.

43. Štajner, S.; Evans, R.; Orăsan, C.; Mitkov, R. What Can Readability Measures Really Tell Us About Text Complexity. In Natural Language Processing for Improving Textual Accessibility (NLP4ITA); European Language Resources Association (ELRA): Istanbul, Turkey, 2012; pp. 1-8.

44. Kincaid, J.P.; Fishburne, R.P., Jr.; Rogers, R.L.; Chissom, B.S. Derivation Of New Readability Formulas (Automated Readability Index, Fog Count And Flesch Reading Ease Formula) For Navy Enlisted Personnel; Institute for Simulation and Training, University of Central Florida: Orlando, FL, USA, 1975.

45. Hunyadi, L.; Vita, L. Statisztika Közgazdászoknak—Statistics for Economists; Központi Statisztikai Hivatal: Budapest, Hungary, 2002.

46. Central Intelligence Agency. The World Factbook. Available online: https://www.cia.gov/library/publications/ the-world-factbook/geos/be.html (accessed on 10 December 2019).

47. Central Statistics Office. Census 2016 Summary Results-Part 1. Available online: https://www.cso.ie/en/ csolatestnews/presspages/2017/census2016summaryresults-part1/ (accessed on 10 December 2019).

48. European Commission. Available online: https://ec.europa.eu/info/index_en (accessed on 10 December 2019).

49. Flesch, R. How to Write Plain English: A Book for Lawyers and Consumers; Harper \& Row: New York, NY, USA, 1979; ISBN 0060112786.

50. Hofstede, G.; Hofstede, G.J.; Minkov, M. Cultures and Organizations: Software of the Mind, Third Edition (Business Skills and Development); McGraw-Hill Education: New York, NY, USA, 2010; ISBN 978-0071664189.

51. Eurostat. Real GDP Per Capita. Available online: https://ec.europa.eu/eurostat/web/products-datasets/-/sdg 08_10 (accessed on 10 December 2019).

52. United Nations Development Programme. Human Development Reports. Available online: http://hdr.undp. org/en/2019-report (accessed on 10 December 2019).

53. European Commission. SCIENCE, TECHNOLOGY AND INNOVATION, R\&D Expenditure (as \% of GDP). Available online: https://ec.europa.eu/eurostat/web/science-technology-innovation (accessed on 10 December 2019). 
54. Bašnáková, J.; Brezina, I.; Masaryk, R. Dimensions of culture: The case of slovakia as an outlier in hofstede's research. Cesk. Psychol. 2016, 60,1-14.

55. Kolman, L.K.; Noorderhaven, N.G.; Hofstede, G.; Dienes, E. Cross-cultural differences in Central Europe. J. Manag. Psychol. 2003, 18, 76-88. [CrossRef] 